\title{
PENGARUH LINGKUNGAN KERJA TERHADAP KINERJA PEGAWAI PADA INSTANSI PEMERINTAH DAERAH KABUPATEN MUSI BANYUASIN \\ (STUDI KASUS DINAS PERTAMBANGAN DAN ENERGI KABUPATEN MUSI BANYUASIN)
}

\author{
Oleh : \\ Hendry Wijaya \\ Dosen Fakultas Ekonomi STIE Rahmaniyah Sekayu \\ Email : hendrywijaya2001@gmail.com \\ Emi Susanty \\ Mahasiswa STIE Rahmaniyah Sekayu
}

\begin{abstract}
Abstrak
Pada penelitian ini terdapat dua variabel yang akan melewati proses pengolahan dan pembahasan data sehingga dapat ditarik kesimpulan, kedua variabel tersebut adalah Lingkungan Kerja (variabel bebas) dan Kinerja Pegawai (variabel terikat). Penelitian ini bertujuan untuk mengetahui seberapa besar Pengaruh Lingkungan Kerja Terhadap Kinerja Pegawai Pada Instansi Pemerintah Daerah Kabupaten Musi Banyuasin (Studi Kasus Dinas Pertambangan Dan Energi Kabupaten Musi Banyuasin). Penelitian ini dilakukan disalah satu instansi pemerintah daerah Kabupaten Musi Banyuasin yaitu pada Dinas Pertambangan Dan Energi Kabupaten Musi Banyuasin. Penelitian ini mengggunakan data primer maupun sekunder. Teknik analisis penelitian ini menggunakan metode kuantitatif dimana menggunakan persamaan statistika dalam mengolah dan melakukan pembahasan data yang diperoleh dari responden melalui media kuesioner. Hasil penelitian ini menunjukkan bahwa terdapat pengaruh antara Lingkungan Kerja terhadap Kinerja Pegawai dengan besaran skor pengaruh hasil uji regresi adalah sebesar 0,470 .
\end{abstract}

Kata kunci: Lingkungan Kerja, Kinerja Pegawai

\section{PENDAHULUAN}

\section{Latar Belakang Penelitian}

Perkembangan teknologi yang sangat pesat membawa perubahan dalam kehidupan dan perkembangannya tidak dapat dihindarkan. Manajemen sumber daya manusia merupakan bagian dari manajemen keorganisasian yang memfokuskan diri pada unsur sumber daya manusia. Tugas manajemen sumber daya manusia adalah mengelola unsur manusia secara baik agar diperoleh tenaga kerja yang puas akan pekerjaannya.

Di dalam organisasi, manusia merupakan unsur yang terpenting dalam suatu organisasi. Tanpa peran manusia meskipun berbagai faktor yang dibutuhkan itu telah tersedia, organisasi tidak akan berjalan. Karena manusia merupakan penggerak dan penentu jalannya suatu organisasi. Oleh karena itu hendaknya organisasi memberikan arahan yang positif demi tercapainya tujuan organisasi.Sumber daya yang dimiliki instansi pemerintah tidak akan memberikan hasil yang optimum apabila tidak didukung oleh sumber daya manusia yang mempunyai kinerja yang optimum.

Hal ini menunjukkan bahwa sumber daya manusia merupakan kunci pokok yang harus diperhatikan dengan segala kebutuhannya. Memahami pentingnya keberadaan SDM di era global saat ini salah satu upaya yang harus dicapai oleh instansi pemerintah adalah dengan meningkatkan kualitas SDM. Dengan meningkatkan kualitas sumber daya manusia diharapkan karyawan dapat 
meningkatkan kinerjanya. Kinerja karyawan merupakan suatu tindakan yang dilakukan karyawan dalam melaksanakan pekerjaan yang diberikan instansi pemerintah. Setiap instansi pemerintah selalu mengharapkan pegawai mempunyai prestasi, karena dengan memiliki karyawan yang berprestasi akan memberikan sumbangan yang optimal bagi instansi pemerintah. Selain itu, dengan memiliki pegawai yang berprestasi dapat meningkatkan kinerja instansi pemerintahnya. Dengan kata lain kelangsungan suatu instansi pemerintah itu ditentukan oleh kinerja pegawai .

Usaha untuk meningkatkan kinerja karyawan, diantaranya dengan memperhatikan lingkungan kerja. Lingkungan kerja merupakan segala sesuatu yang ada disekitar para pekerja yang dapat mempengaruhi dirinya dalam menjalankan tugas-tugas yang dibebankan. Kondisi kerja adalah keadaan dimana tempat kerja yang baik meliputi lingkungan fisik dan lingkungan non fisik yang dapat memberikan kesan menyenangkan, aman, tentram dan lain sebagainya.

Apabila kondisi kerja baik maka hal tersebut dapat memacu timbulnya rasa puas dalam diri karyawan yang pada akhirnya dapat memberikan pengaruh positif terhadap kinerja karyawan, begitu sebaliknya, apabila kondisi kerja buruk maka karyawan tidak akan mempunyai kepuasan dalam bekerja.

Kondisi lingkungan kerja yang nyaman akan mempengaruhi pegawai bekerja lebih giat dan konsentrasi menyelesaikan tugas-tugasnya sesuai jadwal.Keberhasilan peningkatan kinerja menuntut instansi mengetahui sasaran kinerja. Jika sasaran kinerja ditumbuhkan dari dalam diri karyawan akan membentuk suatu kekuatan diri dan jika situasi lingkungan kerja turut menunjang maka pencapaian kinerja akan lebih mudah, instansi yang mempunyai lingkungan kerja yang baik dan nyaman akan memberikan motivasi bagi pegawai untuk meningkatkan kinerjanya. Selain itu kondisi kerja yang baik akan membantu mengurangi kejenuhan dan kelelahan, sehingga diharapkan dapat meningkatkan kinerja karyawan. Selanjutnya, setiap karyawan atau individu yang bekerja dalam suatu instansi pemerintah mempunyai keinginan untuk mendapatkan gaji yang sesuai dan cocok dengan harapannya jika mereka mendapatkan gaji yang sesuai dengan harapannya, maka mereka akan lebih bersemangat dalam bekerja.

Peningkatan kinerja karyawan di instansi pemerintah dapat ditempuh dengan beberapa cara, misalnya melalui pemberian kompensasi yang layak, pemberian motivasi, menciptakan lingkungan kerja yang kondusif, serta pendidikan dan pelatihan. Oleh karena itu, karyawan diharapkan dapat memaksimalkan tanggung jawab mereka setelah dibekali dengan pendidikan dan pelatihan yang berkaitan dengan implementasi pekerjaan mereka.

Dinas Pertambangan dan Energi merupakan salah satu intansi Pemerintah Daerah yang di beri tugas menyusun perencana dan mengendalikan penambangan jaringan listrik. Sesuai dangan Peraturan Daerah Propinsi Daerah Tingkat 1 Sumatera Selatan Nomor 11 Tahun 1998 pada tanggal 6 Agustus 1988 dibentuklah Cabang Dinas Pertambangan Propinsi Daerah Tingkat 1 Sumatera Selatan yang didirikan di Sekayu Kabupaten Musi Banyuasin. Kemudian pada tahun 2000 cabang Dinas Pertambangan tidak lagi menjadi Dinas Cabang, tetapi berubah menjadi Dinas Pertambangan dan Energi Kabupaten Musi Banyuasin yang dibentuk sesuai dengan Peraturan Daerah Kabupaten Musi Banyuasin No 21 Tahun 2000 dengan tugas pokok dan fungsinya tercantum dalam surat keputusan Bupati Musi Banyuasin nomor 526 Tahun 2000.

Pertambangan adalah rangkaian kegiatan penambangan (penggalian), pengelolahan, pemanfaatan yang bertujuan 
untuk mencapai hasil sesuai dengan misi suatu organisasi. Oleh karena itu untuk berjalannya kegiatan yang ada di Dinas Pertambangan dan Energi harus didukung dengan kinerja pegawai yang mengelola dan bekerja di bidang mereka masingmasing.

Adanya tugas dan tanggung jawab dari setiap pegawai dalam melaksankan tugas mereka, maka dibutuhakan kondisi yang dapat memberikan semagat untuk para pegawai dalam melaksankan pekerjaan mereka, salah satunya kondisi Lingkungan Kerja yang nyaman baik dari segi faktor fisikberupa : peralatan kerja, suhu tempat kerja, kesesakan dan kepadatan, kebisingan, luas ruang kerja, maupun faktor non fisik berupa : hubungan kerja yang trebentuk di instansi antara atasan dengan bawahan serta sesama pegawai merupakan hak para karyawan dan kewajiban dari pihak perusahaan untuk mendukung kontribusi para karyawannya untuk meningkatkan kinerja pegawai dan dapat mencapai tujuan yang telah ditentukan.

Berdasarkan uraian diatas tersebut maka dilakukan penelitian dengan judul "Pengaruh Lingkungan Kerja Terhadap Kinerja Pegawai Pada Instansi Pemerintah Daerah Kabupaten Musi Banyuasin ( Studi Kasus Dinas Pertambangan Dan Energi Kabupaten Musi Banyuasin )".

\section{Rumusan Masalah}

Berdasarkan latar belakang masalah, maka penulis mencoba merumuskan permasalahan yang timbul di Dinas Pertambangan Dan Energi Kabupaten Musi Banyuasin yaitu seberapa besar Pengaruh Lingkungan Kerja Terhadap Kinerja Pegawai Pada Instansi Pemerintah Daerah Kabupaten Musi Banyuasin ( Studi Kasus Dinas Pertambangan Dan Energi Kabupaten Musi Banyuasin?

\section{Tujuan Penelitian}

Adapun yang menjadi tujuan dalam penelitian ini adalah untuk mengetahui seberapa besar Pengaruh Lingkungan
Kerja Terhadap Kinerja Pegawai Pada Instansi Pemerintah Daerah Kabupaten Musi Banyuasin (Studi Kasus Dinas Pertambangan Dan Energi Kabupaten Musi Banyuasin).

\section{TIJAUAN KEPUSTAKAAN. Pengertian Lingkungan Kerja}

Menurut Nitisemito (2007), menjelaskan bahwa Lingkungan Kerja merupakan segala sesuata yang ada di sekitar karyawan dan dapat mempengaruhi karyawan dalam menjalankan tugas-tugas yang dibebankan. Mardiana (2005), mengemukakan bahwa Lingkungan Kerja merupakan tempat karyawan melakukan pekerjaan atau aktivitas sehari-hari.

Dari penjelasan diatas dapat kesimpulkan bahwa Lingkungan Kerja adalah segala yang berada disekitar karyawan yang mempengaruhi dirinya dalam menjalankan dan menyelesaikan tugas-tugas yang diberikan kepadanya dalam suatu wilayah, sehigga penelitian Lingkungan Kerja lebih diarahkan kepada bagaimana pegawai dapat merasa aman, nyaman, tentram, puas dalam menyelesaikan pekerjaan dalam ruangan kerjanya.

\section{Faktor-Faktor Lingkungan Kerja}

Mangkunegara (2006: 51), menjelaskan bahwa secara garis besar, Lingkungan Kerja di pengaruhi oleh faktor fisik dan non fisik dimana faktor fisik berupa :

1. Kebersihan, lingkungan yang bersih dapat menimbulkan perasaan yang nyaman dan senang, sehingga dapat mempengaruhi semangat kerja seseorang.

2. Pertukaran udara, pertukaran udara yang baik akan menyehatkan badan dan menimbulkan kesegaran,sehingga dapat semangat kerja seseorang.

3. Penerangan, penyediaan penerangan yang cukup tetapi tidak menyilaukan akan menjadi suatu pekerjaan dapat di selesaikan dengan lebih baik dan lebih teliti. 
4. Temperatur, menurut hasil penelitian untuk tingkat temperatur akan memberikan pengaruh yang berbeda. Keadaan tersebut tidak mutlak berlaku bagi setiap pegawai karena kemampuan beradaptasi tiap pegawai berbeda, tergantung di daerah bagaimana pegawai dapat hidup.

5. Kebisingan, kebisingan dalam sebuah ruangan harus dikurangi sebisamungkin, hal ini dikarenakan kebisingan dapat mengurangi kesehatan seseorang serta mengacaukan konsenterasi dalam berkerja.

Sedangkan faktor non fisik berupa hubungan yang terjadi antara karyawan dengan atasan dalam melaksanakan pekerjaan dan hubungan yang terjadi antara karyawan yang satu dengan karyawan yang lain guna untuk meningkatkan Lingkungan Kerja yang baik antara karyawan.

\section{Pengertian Kinerja}

Mangkunegara (2006: 67), berpendapat bahwa kinerja adalah hasil kerja secara kualitas dan kuantitas yang dicapai oleh seseorang pegawai dalam melaksanakan tugasnya sesuai dengan tanggungjawab yang diberikan kepadanya. Menurut Hasibuan (2006: 94), Kinerja adalah pengorbanan jasa, jasmani dan pikiran untuk menghasilkan barang-barang atau jasa-jasa dengan memperoleh imbalan prestasi tertentu.

Menurut beberapa pengertian di atas penulis dapat menyimpulkan bahwa kinerja mempunyai hubungan erat dengan masalah produktivitas karena merupakan indikator dalam menentukan bagaimana usaha untuk mencapai tingkat produktivitas yang tinggi dalam suatu perusahaan/instansi. Sehubungan dengan hal tersebut maka upaya untuk mengadakan penilaian terhadap kinerja di suatu organisasi merupakan hal yang sangat penting.
Rivai (2009: 48), menyatakan bahwa peranan kinerja dapat meningkatkan motivasi dan kepuasan pegawai agar dapat meningkatkan kinerja yang efektif dan efisien sistem manajemen kinerja harus :

1. Konsisten dengan misi strategis sebuah perusahaan

2. Bermanfaat sebagai alat pengembangan

3. Berguna sebagai alat administrative

4. Sesuai dengan hukuman dan berkaitan dengan pekerjaan

5. Dipandang adil secara umum oleh karyawan

6. Efektif dalam mendukung kinerja karyawan.

\section{Faktor yang Mempengaruhi Kinerja}

Menurut Mathis (2006: 113), kinerja karyawan dipengaruhi oleh tiga faktor utama yaitu :

1. Kemampuan individual untuk melakukan perkerjaan tersebut.

Kemampuan individual karyawan ini mencakup bakat, minat dan faktor kepribadian. Tingkat kemampuan individual adalah bahan mentah yang dimiliki seorang karyawan seperti pengetahuan, pemahaman, kemampuan, kecakapan interpersonal, dan kecakapan teknis. Dengan demikian, kemungkinan seorang karyawan akan memiliki kinerja yang baik adalah jika karyawan tersebut memiliki kemampuan individual yang cukup.

2. Tingkat usaha yang dicurahkan

Usaha dari karyawan bagi perusahaan adalah etika kerja, kehadiran dan motivasinya. Tingkat usaha merupakan gambaran motivasi yang diperlihatkan karyawan untuk menyelesaikan pekerjaan yang baik. Oleh karena itu, walaupun karyawan memiliki kemampuan individual untuk mengerjakan pekerjaan, tetapi tidak akan bekerja tanpa tingkat pencurahan usaha yang rendah.

3. Dukungan organisasi

Dalam dukungan organisasional artinya fasilitas apa yang perusahaan sediakan bagi karyawan dapat berupa 
pelatihan, pengembangan, peralatan teknologi, dan manajemen.

\section{Metode Penilaian Kinerja}

Menurut Mahsun (2006: 96), bahwa indikator kinerja terdiri dari :

1. Pelayanan yang tepat waktu dan berkualitas,

2. Tingkat keterampilan pendidikan yang sesuai dengan bidang kerja,

3. Kehadiran/keterlambatan

Menurut Mangkunegara (2006: 33), terdapat beberapa aspek kinerja dapat diukur yaitu :

1. Akurasi (pemenuhan standara kurasi)

2. Prestasi (menyelesaikan tanggungjawab dan tugas)

3. Administrasi (menunjukkan efektivitas administratif)

4. Analitis (analisa secara efektif)

5. Komunikasi (berkomunikasi dengan pihak lain)

6. Kompetensi (menunjukkan kemampuan dan kualitas)

7. Kerjasama (bekerja sama dengan orang lain)

8. Kreativitas (menunjukkan daya imaginasi dan daya kreatif)

9. PengambilanKeputusan (pengambilan keputusan dan pemberian solusi)

10. Pendelegasian (menunjukkan orang yang diberikuasa untuk berbicara atau bertindak bagi orang lain)

11. Dapat diandalkan (menunjukkan sifat yang dapat dipercaya)

12. Improvisasi (peningkatan kualitas atau kondisi yang lebih baik)

13. Inisiatif (mengemukakan gagasan, metode dan pendekatan baru)

14. Inovasi (pengenalan metode dan prosedur baru)

15. Keahlian Interpersonal (hubungan manusiawi)

Berdasarkan teori-teori di atas dapat disimpulkan bahwa kinerja memerlukan indikator-indikator penilaian yang dipengaruhi oleh berbagai faktor apakah faktor internal ataupun faktor eksternal dengan beragam aspek yang dapat diukur dengan berpedoman pada standar tertentu yang terdiri dari aspek kuantitatif dan aspek kualitatif yang berguna untuk mendapatkan feedback guna keperluan perbaikan organisasi secara khusus manajemen pengelolaan sumber daya manusia.

\section{Penelitian Sebelumnya}

Penelitian yang dilakukan oleh Putra et.al. (2013) yang berjudul Pengaruh Lingkungan Kerja Terhadap Kinerja (Studi Pada Karyawan PT. Naraya Telematika Malang) yang menggunakan 2 variabel (variabel terikat dan variabel bebas), yaitu Lingkungan Kerja terhadap Kinerja. Jenis penelitian yang digunakan yaitu penelitian eksplanatori dengan pendekatan kuantitatif.

Jumlah populasi dalam penelitian ini berjumlah 33 orang yang merupakan karyawan PT. Naraya Telematika Malang. Teknik pengambilan sampel yang digunakan oleh peneliti adalah samping jenuh. Analisis data yang digunakan adalah statistik deskriptif dan analisis statistik inferensial. Hasil penelitian ini menunjukan bahwa secara parsial lingkungan kerja fisik $\left(\mathrm{X}_{1}\right)$ dan lingkungan kerja non fisik $\left(\mathrm{X}_{2}\right)$ memiliki pengaruh signifikan terhadap kinerja karyawan $(\mathrm{Y})$. Sementara itu, analisis deskriptif menunjukan bahwa dengan lingkungan kerja yang berada pada tingkat kuat, didapatkan kinerja karyawan yang kuat pula.

\section{Kerangka Pikir Penelitian.}

Untuk mempermudah dalam menjelaskan konsep pada penelitian ini, maka penulis menyusun kerangka pemikiran sebagai berikut : 


\begin{tabular}{|l|l|}
\hline \multicolumn{2}{|c|}{ Lingkungan Kerja } \\
\hline Faktor Fisik, & Faktor Non Fisik, \\
- Peralatan kerja & Mencakup hubungan \\
- Suhu tempat kerja & kerja yang terbentuk di \\
- Kesesakan Dan & instansi antara atasan \\
Kepadatan & dan bawahan serta \\
- Kebisingan & antara sesama Pegawai \\
- Luas ruang kerja & \\
\hline
\end{tabular}

Gambar 1 Kerangka Pemikiran

Berdasarkan gambar diatas menunjukkan bahwa lingkunan kerja (X) adalah Lingkungan Kerja yang terkait dengan kemampuan manusia dan prestasi kerja. Adapun indikatornya : faktor fisik yang terdiri atas peralatan kerja, suhu tempat kerja, kesesakan dan kepadatan, kebisingan, luas ruang kerja dan non fisik mencakup hubungan kerja yang terbentuk di instansi antara atasan dan bawahan serta antara sesama pegawai. Secara ginetis, Setiap individu mempunyai kemampuan untuk menyesuaikan diri terhadap lingkungan pola prilaku tertentu untuk mengulangi masalah lingkungan. Namun demikian pembentukan lingkungan yang mendukung perestasi kerja sangat berpengaruh terhadap kinerja pegawai baik berupa kemapuan individu, tingkat usaha yang dicurahkan dan dukungan organisasi, sehingga Dinas Pertambangan dan energi haruslah mengusahakan Lingkungan Kerja sedemikian rupa agar memberikan pengaruh positif terhadap perkerjaan yang dilakukan pegawai.

Selain itu kemungkinan ada hal-hal yang berada di sekitar pekerjaan yang dianggap tidak berpengaruh terhadap kinerja pegawai dalam melaksanakan tugas-tugas yang di bebenkan, tetapi pada suatu saat ternyata dapat di buktikan bahwa hal itu dapat berpengaruh cukup besar. Berbagai kebijakan dan kegiatan personalia yang dijalankan Dinas Pertambangan dan Energi akan memberikan suatu Lingkungan Kerja yang menyenangkan atau tidak menyenangkan bagi pegawai dalam perusahaan.

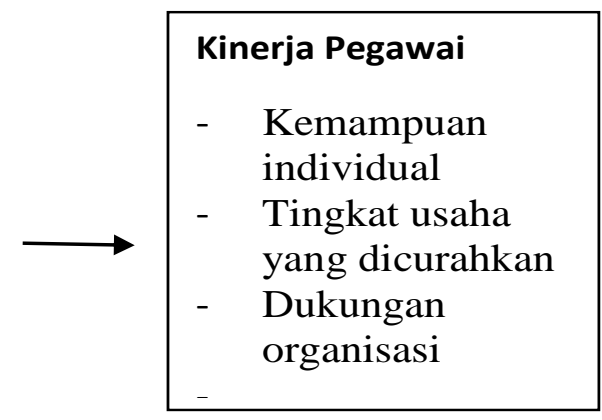

\section{Hipotesis.}

Hipotesis adalah prediksi dari hasil yang dimungkinkan atau merupakan dugaan sementara terhadap suatu persoalan. Dalam penelitian ini dipengaruhi oleh 2 (dua) hipotesis yaitu : Ho : diduga tidak ada pengaruh signifikan antara Lingkungan Kerja dengan kinerja pegawai di Dinas Pertambangan dan Energi Kabupaten Musi Banyuasin.

$\mathrm{Ha}$ : diduga ada pengaruh signifikan antara Lingkungan Kerja dengan kinerja pegawai di Dinas Pertambangan danEnergi Kabupaten Musi Banyuasin.

\section{METODE PENELITIAN \\ Lokasi Penelitian.}

Objek penelitian ini dilakukan pada Dinas Pertambangan dan Energi Kabupaten Musi Banyuasin yang beralokasi di jalan Kolonel Whid Udin LK. VI Kec. Sekayu Kabupaten Musi Banyuasin.

\section{Data Yang Digunakan.}

Data yang digunakan dalam penelitian ini adalah :

1. Data primer adalah data yang diperoleh secara langsung dari pihakpihak terkait yang menjadi sumber penelitian di lapangan melalui wawancara.

2. Data sekunder adalah data yang digunakan untuk mendukung data primer yang diperoleh dari studi kepustakaan, dokumentasi, peraturanperaturan tertulis yang ada kaitannya dengan permasalahan serta literatur. 


\section{Populasi dan Sampel}

\section{Populasi}

Dalam penelitian ini populasi yang diambil yaitu dari di Dinas Pertambangan dan Energi Kabupaten Musi Banyuasin berjumlah 39 orang.

\section{Sampel}

Dikarenakan objek dalam penelitian ini sangat sedikit atau kurang dari 100 dengan demikian penulis dalam penelitian ini mengunakan Sampling Jenuh karena semua anggota dijadikan sampel, maka sampel pada penelitian ini berjumlah 39 responden.

\section{Teknik Pengumpulan Data}

Dalam Penelitian ini, teknik yang digunakan penulis untuk memperoleh dan mengumpulkan data penelitian yang diperlukan menurut Sugiyono (2007) adalah :
1. Wawancara

2. Studi Dokumentasi,

3. Observasi

4. Studi Kepustakaan.

\section{Definisi Operasional Variabel}

Dalam penelitian ini perlu dijelaskan defenisi operasional guna menghindari kesalahan dalam mengartikan variabelvariabel yang di analisis atau untuk membatasi permasalahan.

a. Variabel Bebas, Dalam penelitian ini yang menjadi Variabel Bebas adalah "Lingkungan Kerja".

b. Variabel Terikat, Dalam penelitian ini yang menjadi Variabel Terikat adalah "kinerja pegawai".

Tabel 1.

Operasional Variabel

\begin{tabular}{|c|c|c|c|c|c|}
\hline No. & VARIABEL & DIMENSI & INDIKATOR & $\begin{array}{c}\text { ITEM } \\
\text { PERTANYAN }\end{array}$ & $\begin{array}{c}\text { SKALA } \\
\text { PENGUKURAN }\end{array}$ \\
\hline \multirow[t]{2}{*}{1.} & $\begin{array}{l}\text { Variabel } \\
\text { Lingkungan } \\
\text { Kerja }(X)\end{array}$ & Faktor Fisik & $\begin{array}{l}\text { 1. Peralatan kerja. } \\
\text { 2. Suhu tempat kerja. } \\
\text { 3. Kesesakan dan } \\
\text { kepadatan. } \\
\text { 4. Kebisingan. } \\
\text { 5. Luas ruangan kerja. }\end{array}$ & $\begin{array}{c}1-2 \\
3 \\
4-5 \\
6 \\
7-8\end{array}$ & $\begin{array}{l}\text { Skala } \\
\text { Ordinal }\end{array}$ \\
\hline & & Non Fisik & $\begin{array}{l}\text { 1. Hubungan dengan } \\
\text { atasan. } \\
\text { 2. Hubungan dengan } \\
\text { sesama pegawai }\end{array}$ & $\begin{array}{c}9 \\
10\end{array}$ & $\begin{array}{l}\text { Skala } \\
\text { Ordinal }\end{array}$ \\
\hline 2. & $\begin{array}{l}\text { Variabel } \\
\text { Kinerja }(\mathrm{Y})\end{array}$ & $\begin{array}{l}\text { 1. Kemampuan } \\
\text { individual } \\
\text { 2. Tingkat } \\
\text { usaha yang } \\
\text { dicurahkan } \\
\text { 3. Dukungan } \\
\text { organisasi }\end{array}$ & $\begin{array}{l}\text { 1. Inisiatif kerja yang baik } \\
\text { dalam bekerja. } \\
\text { 2. Memiliki } \\
\text { tanggungjawab dalam } \\
\text { bekerja. } \\
\text { 3. Tingkat kehadiran kerja } \\
\text { yang tinggi. } \\
\text { 4. Memiliki prinsip } \\
\text { efesiansi waktu, biaya } \\
\text { dan tenaga. } \\
\text { 5. Keterampilan dan } \\
\text { pengetahuan pegawai } \\
\text { dalam penyelesaian } \\
\text { pekerjaan. }\end{array}$ & $\begin{array}{c}1-2 \\
3-4 \\
5-6 \\
7-8 \\
9-10\end{array}$ & $\begin{array}{l}\text { Skala } \\
\text { Ordinal }\end{array}$ \\
\hline
\end{tabular}




\section{Teknik Analisis Data}

Dalam penelitian ini penulis menggunakan metode kuantitatif yaitu penelitian ilmiah yang sistematis terhadap bagian-bagian dan fenomena serta hubungan-hubungannya. Tujuan penelitian kuantitatif adalah mengembangkan dan menggunakan model-model matematis, teori-teori atau hipotesis yang berkaitan dengan fenomena alam. Proses pengukuran adalah bagian yang sentral dalam penelitian kuantitatif karena hal ini memberikan hubungan yang fundamental antara pengamatan empiris dan ekspresi matematis dari hubungan-hubungan kuantitatif.

Adapun tahapan analisis kuantitatif yang digunakan untuk menganalisis data dalam penelitian ini adalah :
1. Uji Validitas

2. Uji Reliabilitas

3. Analisis Regresi Sederhana

4. Analisis Korelasi (R) dan Koefisien Determinanasi ( $u j i \mathrm{R}^{2}$ )

5. Uji Hipotesis (Uji t)

\section{HASIL DAN PEMBAHASAN}

1. Uji Validitas.

Uji validitas dilakukan untuk mengetahui tingkat kevalidan indikator yang digunakan sebagai alat ukur variabel. Pengujian validitas menggunakan korelasi bivariate yang dilakukan dengan menghitung korelasi antara skor masingmasing butir pertanyaan dengan total skor variabel dengan ketentuan sig. nilai sig. (2tailed) $<0,05$ berarti valid. Berikut ini hasil uji validitas masing-masing indikator:

Tabel 2.

Hasil Uji Validitas Instrumen Penelitian

\begin{tabular}{|c|c|c|c|c|c|c|}
\hline Variabel & Item & $\begin{array}{c}\text { Korelasi } \\
\text { Product Moment }\end{array}$ & $\begin{array}{c}\text { Nilai } \\
\text { R Tabel }\end{array}$ & $\begin{array}{c}\text { Sig. } \\
\text { (2 Tailed) }\end{array}$ & $\begin{array}{c}\text { Taraf Sig } \\
(\boldsymbol{\alpha}=\mathbf{0 , 0 5})\end{array}$ & $\begin{array}{c}\text { Keterangan } \\
\text { Hasil }\end{array}$ \\
\hline \multirow{6}{*}{} & X.1 & 0,876 & 0,3160 & 0,000 & 0.05 & Valid \\
& X.2 & 0,802 & 0,3160 & 0,000 & 0,05 & Valid \\
& X.3 & 0,799 & 0,3160 & 0,000 & 0,05 & Valid \\
& X.4 & 0,686 & 0,3160 & 0,000 & 0,05 & Valid \\
X.5 & 0,350 & 0,3160 & 0,000 & 0,05 & Valid \\
& X.6 & 0,799 & 0,3160 & 0,000 & 0,05 & Valid \\
& X.7 & 0,686 & 0,3160 & 0,000 & 0,05 & Valid \\
& X.8 & 0,876 & 0,3160 & 0,000 & 0,05 & Valid \\
& X.9 & 0,802 & 0,3160 & 0,000 & 0,05 & Valid \\
& X.10 & 0,799 & 0,3160 & 0,000 & 0,05 & Valid \\
\hline \multirow{6}{*}{ Y.1 } & 0,525 & 0,3160 & 0,001 & 0,05 & Valid \\
& Y.2 & 0,599 & 0,3160 & 0,000 & 0,05 & Valid \\
& $Y .3$ & 0,496 & 0,3160 & 0,001 & 0,05 & Valid \\
& Y.4 & 0,609 & 0,3160 & 0,000 & 0,05 & Valid \\
& Y.5 & 0,485 & 0,3160 & 0,002 & 0,05 & Valid \\
& Y.6 & 0,525 & 0,3160 & 0,001 & 0,05 & Valid \\
& Y.7 & 0,599 & 0,3160 & 0,000 & 0,05 & Valid \\
& Y.8 & 0,496 & 0,3160 & 0,000 & 0,05 & Valid \\
& Y.9 & 0,609 & 0,3160 & 0,002 & 0,05 & Valid \\
& Y.10 & 0,485 & & & & Valid \\
\hline
\end{tabular}

Sumber : Data primer (diolah). 2016

korelasi bivariate menunjukan korelasi yang signifikan antara skor item dengan skor total atau masing item dengan ketentuan sig, jika nilai sig. (2-tailed) < 0.05, maka instrument dikatakan valid. bahwa masing-masing butir pertanyaan mempunyai nilai dengan cara membandingkan nilai korelasi masingnilai sig. (2-tailed) $<0,05$ untuk tingkat kepercayaan $95 \%$. semua data tersebut 
valid dan layak untuk diuji ketahapan selanjutnya.

\section{Uji Reliabilitas.}

Uji reliabilitas digunakan untuk mengetahui adanya konsitensi alat ukur dalam penggunaanya. Dengan kata lain alat ukur tersebut mempunyai hasil yang konsisten apabila digunakan berkali-kali pada waktu yang berbeda tehadap penomena atau kejadian yang sama. Reliabelitas adalah derajat ketepatan, ketelitian atau keakuratan yang ditunjukan oleh instrumen pengukuran.

Pengukuran reabilitas instrumen dilakukan pada intem-intem pertanyaan yang memiliki validitas atau instrumen yang valid. Sehingga dari pernyataan tersebut dapat disimpulkan bahwa instrumen yang dinyatakan reliabel adalah instrumen yang memiliki nilai koefisien paling tidak mencapai 0,60. Dalam penelitian ini pengujian dilakukan dengan menganalisa setiap butir pertanyaan yang ada dengan mengunakan formula cronbach's alpha, yang hasilnya dapat diliha pada tabel 3 dibawah ini:

Tabel 3.

Hasil Uji Reabilitas Instrumen Penelitian

\begin{tabular}{|c|c|c|}
\hline Variabel & Cronbach's Alpa & Ket. \\
\hline $\begin{array}{c}\text { Variabel x } \\
\text { Lingkungan Kerja }\end{array}$ & 0,773 & Reliabel \\
\hline $\begin{array}{c}\text { Variabel Y } \\
\text { Kinerja Pegawai }\end{array}$ & 0,730 & Reliabel \\
\hline
\end{tabular}

Sumber : Data primer (diolah). 2016

Berdasakan tabel 3 diatas, dapat dilihat bahwa variabel $\mathrm{X}$ dan variabel $\mathrm{Y}$ masing-masing mempunyai nilai koefisien lebih dari 0.60 sehingga dapat disimpulkan bahwa instrument yang digunakan dinyatakan reliabel (handal) dan bisa diterima karena memiliki nilai koefisien variable $X$ sebesar 0,773 dan nilai koefisien variable $\mathrm{Y}$ sebesar 0,730 .

3. Analisis Regresi Sederhana.
Analisis regresi linier sederhana digunakan dalam penelitian ini dengan tujuan untuk membuktikan hipotesis mengenai pengaruh variabel Lingkungan Kerja terhadap kinerja pegawai. Perhitungan statistik dalam analisis regresi linier sederhana yang digunakan dalam penelitian ini adalah dengan menggunakan bantuan program komputer SPSS For Windows Relase 15.0. Hasil pengolahan data dengan menggunakan program SPSS dapat dilihat pada tabel 4 berikut ini:

Tabel 4.

Koefisien Regresi Sederhana

Coefficients ${ }^{\mathrm{a}}$

\begin{tabular}{|c|c|c|c|c|c|c|}
\hline \multirow{2}{*}{\multicolumn{2}{|c|}{ Model }} & \multicolumn{2}{|c|}{$\begin{array}{l}\text { Unstandardized } \\
\text { Coeff icients }\end{array}$} & \multirow{2}{*}{$\begin{array}{c}\text { Standardized } \\
\text { Coeff icients } \\
\text { Beta } \\
\end{array}$} & \multirow[b]{2}{*}{ t } & \multirow[b]{2}{*}{ Sig. } \\
\hline & & $\mathrm{B}$ & Std. Error & & & \\
\hline \multirow[t]{2}{*}{1} & (Constant) & 21.844 & 3.226 & & 6.771 & .000 \\
\hline & Lingkunga Kerja & .470 & .083 & .680 & 5.636 & .000 \\
\hline
\end{tabular}

Interpretasi dari persamaan regresi sederhana mengenai pengaruh variabel independen yaitu Lingkungan Kerja terhadap variabel dependen yaitu kinerja pegawai dapat dijelaskan sebagai berikut :

$\mathrm{Y}=\alpha+\beta \mathrm{X}+\mathrm{e}$

$Y=21.844+0,470 X$

Persamaan regresi linier sederhana tersebut diatas dapat dijabarkan sebagai berikut:

- $\boldsymbol{\alpha}=$ nilai konstanta sebesar 21,844 menyatakan bahwa jika variabel independen $X$ (Lingkungan Kerja) dianggap tidak ada (nol) maka kinerja pegawai sebesar 21,844 .

- $\boldsymbol{\beta}=0,470$ berarti jika kinerja pegawai meningkat satu poin, maka skor kinerja pegawai akan meningkat sebesar 0,470. Jadi, tanda + menyatakan hubungan searah. Variabel independen $\mathrm{X}$ (Lingkungan Kerja) akan mengakibatkan kenaikan atau penurunan variabel dependen $\mathrm{Y}$ (Kinerja Pegawai). Hal ini dapat dilihat dari persamaan hasil regresi yaitu $y=21.844+0,470 X+e$. 
4. Analisis Korelasi (R) dan Koefisien Determinanasi (uji $\mathrm{R}^{2}$ )

a. Analisis Korelasi (R)

Analisis korelasi (r) digunakan untuk mengukur tinggi rendahnya derajat hubungan antar variabel yang diteliti. Tinggi rendahnya derajat keeratan tersebut dapat dilihat dari koefisien korelasinya.

Table 5.

\section{Koefisien Korelasi}

\begin{tabular}{l|l|r|r|r|}
\multicolumn{7}{c|}{ Model Summary } \\
\hline Model & \multicolumn{1}{|c|}{ R } & R Square & $\begin{array}{c}\text { Adjusted } \\
\text { R Square }\end{array}$ & $\begin{array}{c}\text { Std. Error of } \\
\text { the Estimate }\end{array}$ \\
\hline 1 & $.680^{\mathrm{a}}$ & .462 & .447 & 2.841 \\
\hline
\end{tabular}

a. Predictors: (Constant), Lingkunga Kerja

Berdasarkan tabel 5, didapat nilai korelasi variabel Lingkungan Kerja (r) sebesar 0,680. Dari penafsiran terhadap koefisien korelasi tersebut dapat diketahui bahwa terjadi hubungan positif yang tinggi antara Lingkungan Kerja dan Kinerja Pegawai.

\section{b. Analisis Koefisien Determinanasi $\left(\mathrm{R}^{2}\right)$}

Berdasarkan hasil perhitungan seperti yang dilihat pada tebel 5. bahwa nilai koefisien determinasi ( $\mathrm{R}$ squere $\mathrm{R}^{2}$ ) adalah sebesar 0,462 (46,2\%). Nilai R squere $\left(\mathrm{R}^{2}\right)$ menunjukan bahwa variabel Lingkungan Kerja dapat mempengaruhi kinerja pegawai sebesar $53,8 \%$ sedangkan sisanya dipengaruhi oleh variabel yang tidak dimasukkan dalam penelitian ini.

\section{Uji Hipotesis (Uji t)}

Uji t digunakan untuk menguji apakah terdapat pengaruh positif antara variabel Lingkungan Kerja dan secara individual terhadap kinerja pegawai. Untuk menentukan apakah hipotensis yang diajukan diterima atau ditolak adalah dengan melihat tabel signifikan. Hasil uji t dapat ditunjukan sebagai berikut:

Tabel 6.

Hasil Uji Hipotesis (Uji t)

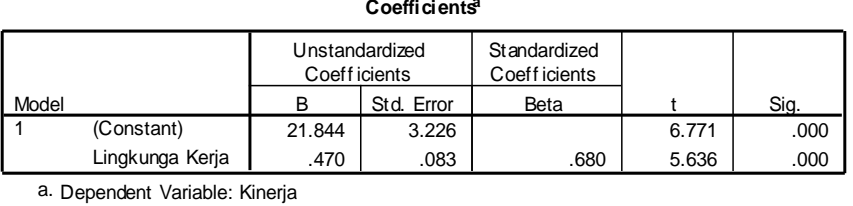

Berdasarkan tabel 6 dapat diketahui bahwa nilai $t_{\text {hitung }}$ adalah sebesar 5.636 sedangkan $t_{\text {tabel }}$ 2,0262 dengan tingkat signifikan 0.000 , oleh karena nilai $t_{\text {hitung }}>$ $\mathrm{t}_{\text {tabel }}$ yaitu $5.636>2,0262$ dan signifikan $0.000<0.05$, maka $\mathrm{H}_{0}$ ditolak dan $\mathrm{H}_{\mathrm{a}}$ diterima, artinya bahwa ada hubungan secara signifikan antara Lingkungan Kerja dengan Kinerja Pegawai.

\section{KESIMPULAN DAN SARAN Kesimpulan}

Berdasarkan dari permasalah yang dibahas pada rumusan masalah diatas, maka hasil penelitian ini dapat disimpulkan sebagai berikut :

a. Berdasarkan indikator dari kedua variabel dinyatakan valid karena nilai sig. (2-tailed) $<0.05$ dan berdasarkan hasil uji reabilitas bahwa indikator yang digunakan dapat dipercaya atau handal sebagai alat ukur variabel karena berdasarkan hasil yang telah diperoleh dari semua variabel menunjukan cronbach's Alpa $>0.06$.

b. Uji Regresi Linier Sederhana persamaan regsesi $\mathrm{Y}=21,844+$ $0,470 \mathrm{X}$ artinya Lingkungan Kerja memberikan pegaruh sebesar 0,470 pada kinerja pegawai pada Dinas Pertambangan Dan Energi Kabupaten Musi Banyuasin.

c. Dari hasil analisis korelasi didapat nilai korelasi variabel Lingkungan Kerja (X) sebesar 0,680. Dari penafsiran terhadap koefisisen korelasi tersebut dapat diketahui bahwa terjadi hubungan positif yang tinggi antara Lingkungan Kerja dan kinerja pegawai pada Dinas Pertanian dan Pertenakan Kabupaten Musi Banyuasin.

d. Koefisien Determinasi ( $\mathrm{R}$ Squere) sebesar 0.462 menunjukan bahwa variabel Lingkungan Kerja mempengaruhi kinerja pegawai pada 
Dinas Pertanian dan Pertenakan Kabupaten Musi Banyuasin sebesar $(46,2 \%)$, sedangkan sisanya sebesar $53,8 \%$ dipengaruhi oleh variabel lain yang tidak dimasukan dalam penelitian ini.

e. Hasil Uji Hipotesis (Uji T) penelitian ini dapat disimpulkan bahwa nilai $t_{\text {hitung }}$ adalah sebesar 5.636 sedangkan $t_{\text {tabel }}$ adalah sebesar 2,0262 dengan tingkat signifikan 0.000 , oleh karena nilai $t_{\text {hitung }}>t_{\text {tabel }}$ yaitu $5.636>2,0262$ maka $\mathrm{H}_{\mathrm{o}}$ diterima dan $\mathrm{H}_{\mathrm{a}}$ ditolak. Artinya bahwa ada hubungan secara signifikan antara Lingkungan Kerja dengan kinerja pegawai.

\section{Saran}

Berdasarkan simpulan diatas baik yang menyangkut teoritis maupun bersifat uraian yang telah dikemukakan, maka diberikan beberapa saran yang kiranya dapat bermanfaat bagi pihak-pihak yang berkepentingan. Adapun saran-saran yang penulis dapat berikan adalah :

a. Bagi pihak yang melakukan penelitian yang sama, disarankan untuk meneliti varaibel-variabel yang belum diteliti dalam penelitian ini. Karena dari penelitian ini diketahui masih ada faktor-faktor lain yang mempengaruhi kinerja pegawai.

b. Hendaknya ada penelitian lanjutan guna menyempurnakan penelitian dikemudian hari.

\section{DAFTAR PUSTAKA}

Mahsum, M. 2006. Manajemen Kinerja, Penerbit Prestasi Pustaka Publisher, Jakarta.

Mangkunegara, Anwar Prabu 2006, Manjemen Sumber Daya Manusia Perusahaan, Remaja Rosdakarya, Bandung.

Mardiana. 2005. Manajemen Produksi. Jakarta: Penerbit Badan Penerbit IPWI.
Mathis, Robert L dan John H Jackson, 2006, Human Resource Management, terjemahan, Edisi Kesepuluh, Jakarta, Salemba Empat.

Nitisemito, Alex S, 2007. Manajemen Personalia. Jakarta: Ghalia Indonesia.

Putra, Fariz Ramanda, Utami, Hamidah Nayati \& Hakam, M.S. 2013. "Pengaruh Lingkungan Kerja Terhadap Kinerja (Studi Pada Karyawan PT. Naraya Telematika Malang)". Jurnal Administrasi Bisnis, Vol 6, No 1.

Rivai, Veithzal. 2009. Manajemen Sumber Daya Manusia Untuk Perusahaan Dari Teori ke Praktik. Jakarta: Raja Grafindo Persada

Sugiyono. 2007. Metode Penelitian Kuantitatif Kualitatif dan $R \& D$. Bandung: Alfabeta. 